\title{
Development and Quality of Fiber Enriched Functional Spent Hen Nuggets Incorporated with Hydrated Wheat Bran
}

\author{
Sandeep Narayan Rindhe*, Manish Kumar Chatli, Rajesh Vishwanath Wagh, \\ Pavan Kumar, Om Prakash Malav and Nitin Mehta
}

Department of Livestock Products Technology, College of Veterinary Science, Guru Angad

Dev Veterinary and Animal Sciences University, Ludhiana-141004, (Punjab), India

*Corresponding author

\section{A B S T R A C T}

In the present investigation, the effect of hydrated wheat bran on physico-chemical, textural, color and sensory qualities of spent hen meat nuggets were studied. Moisture,

\begin{tabular}{|l|}
\hline K e y w o r d s \\
$\begin{array}{l}\text { Wheat bran, Fiber } \\
\text { enriched nuggets }\end{array}$ \\
\hline Article Info \\
\hline $\begin{array}{l}\text { Accepted: } \\
\text { 24 September } 2018 \\
\text { Available Online: } \\
\text { 10 December } 2018\end{array}$ \\
\hline \hline
\end{tabular}
protein, fat and $\mathrm{a}_{\mathrm{w}}$ decreased significantly $(\mathrm{P}<0.05)$, while ash, fiber, water holding capacity, emulsion stability and cooking yield increased significantly $(\mathrm{P}<0.05)$ with incorporation of wheat bran. It was found that addition of hydrated wheat bran significantly $(\mathrm{P}<0.05)$ increased moisture retention and fat retention. Instrumental color profile, lightness $\left(L^{*}\right)$ and yellowness $\left(b^{*}\right)$ increased while redness $\left(a^{*}\right)$ decreased $(\mathrm{P}<0.05$ with addition of hydrated wheat bran. The effect of addition of hydrated wheat bran was also observed on instrumental textural properties of nuggets. Hardness, chewiness and gumminess of spent hem meat nuggets were higher, whereas springiness, stringiness, cohesiveness and resilience were lower in treated products as compared to control. All the sensory properties decreased significantly $(\mathrm{P}<0.05)$ with the addition of hydrated wheat bran however, sensory panelists rated the nuggets to be of 'very good to excellent' quality. It is concluded that fiber enriched spent hen meat nuggets can be successfully developed with the incorporation of pre-hydrated $8 \%$ wheat bran.

\section{Introduction}

Functional meat can be produced by either nutritional or processing interventions. Processing interventions are more precise, repeatable and provide opportunities to develop strategies for the improvement of functionality of meat and meat products.

Functional meat products can be developed by various strategies like reduction of fat, saturated fatty acids, salt and nitrite as well as by the incorporation of functional ingredients like fibres (Barros et al., 2018). Consumption of diet containing dietary fiber is linked with control of body weight, reduction of cardiovascular diseases risk and decrease in chronic health problems (WHO/FAO, 2003; Slavin, 2005). Dietary fiber has various beneficial effect like it increase bulkiness of diet, form gel during digestion, slowing of glucose absorption, trapping of carbohydrates, regulate blood pressure and lowering LDL cholesterol (Dhingra et al., 2012). 
Daily dietary fibre requirement recommended by National Academy of Sciences (USA) is 30-38 $\mathrm{g}$ and 21-26 $\mathrm{g}$ for men and women, respectively. Meat products formulated with optimal levels of dietary fibre gain interest in the design of new functional foods along with the increase in product yield (Cappa et al., 2015). Cereal agro-industry by-products viz., wheat bran, rice bran etc the potential of imparting health benefits to consumers and reduces the overall cost of production of meat products. Cereal brans containing dietary fiber act as a functional ingredient as stabilizer, fat replacer, binder, volume enhancer in emulsion based meat products (Kumar et al., 2011).

Byproduct from milling industry like wheat bran contains $11.58 \%$ crude fiber, $48.69 \%$ total dietary fiber, $46.59 \%$ insoluble dietary fiber and $2.10 \%$ soluble dietary fiber (Yadav and Malik, 2016). Wheat bran is good source of fiber, protein and minerals therefore recommended for prevention and treatment of constipation and diabetes with cancer reducing risk (Haripriya and Premakumari, 2010). Several studies have been reported for dietary fiber enrichment from cereal brans in chicken sausages (Yadav et al., 2016), pork sausages (Khate, 2007), meat balls (Yasarlar et al., 2007) and beef patties (Saricoban et al., 2009).

Difference in composition and structural properties of dietary fiber, directs the nutritional and technical properties of meat products. Hence, this study was carried out to evaluate whether hydrated wheat bran as a dietary fiber could be successfully incorporated in spent hen meat nuggets with an effort to improve our understanding of how physico-chemical, textural, color and sensory qualities affected by addition.

\section{Materials and Methods}

Layer bird of white leghorn (WLH) breed of age 72 weeks procured from poultry farm of
GADVASU, Ludhiana were slaughtered and dressed in the experimental slaughter house of the Department of Livestock Products Technology, COVS, GADVASU, Ludhiana as per standard procedures and guidelines for animal welfare and ethics. Dressed carcasses were packed in LDPE bags and stored overnight at $4 \pm 1^{0} \mathrm{C}$ temperature. The dressed birds were manually deboned and meat free from visible fat and connective tissue, was packed in LDPE bags and frozen for $24 \mathrm{hrs}$. Wheat bran procured form Bagrry's India Ltd. New Delhi. Other material including spices, condiments and refined wheat flour used in the present study were procured from local market.

\section{Preparation of spent hen meat nuggets}

Spent hen meat nuggets (SHMN) were prepared as per standardized formulation in our laboratory mentioned in Table 1 . Emulsion was prepared with the incorporation of different levels of hydrated wheat bran $(0$, 4, 8 and $12 \%$ ). Wheat bran levels mentioned earlier were selected on the basis of available literature and preliminary experiments. Frozen deboned meat was thawed at $4 \pm 1{ }^{\circ} \mathrm{C}$ and minced using meat mincer (Eskimo grinder, MEW-714-H82, MADO, Dornhan, Germany). Chopping of minced meat was done in bowl chopper (Model: TC11, Scharfen, Germany) along with salt, sodium nitrite and sodium tripolyphosphate for three minutes. Thereafter, chilled water and refined oil were added slowly and chopped for 2 minutes to develop emulsion. The wheat bran was hydrated in the added chilled water of the formulation for 30 min. Thereafter, it was thoroughly mixed in the chopper along with other emulsion additives. The spent hen meat emulsions were filled compactly in aluminum molds (18 x 12 x $4 \mathrm{~cm}$ ) with $600 \mathrm{gm}$ of meat emulsion. The air bubbles were removed by tapping molds for 4-5 times on plain surface and closed tightly. The molds filled with emulsion were 
subjected to steam in an autoclave and cooked at $121^{\circ} \mathrm{C}, 15$ psi for 15 minutes followed by cooling to room temperature. The cooked products after removing from molds cut in to rectangular meat nuggets and subjected for analysis.

\section{Analysis}

pH

$\mathrm{pH}$ of samples was determined as per the method of Trout et al., (1992) using digital $\mathrm{pH}$ meter (Elico, Model LI 127, Elico Limited Hyderabad, India). After blending $10 \mathrm{~g}$ of cooked product(s) with $100 \mathrm{ml}$ of deionized water for 2 min to get suspension, the $\mathrm{pH}$ was measure by placing combined glass electrode.

\section{Water activity}

Water activity was measured by using portable digital water activity meter at $25^{\circ} \mathrm{C}$ (Rotronix HYGRO Palm AW1 Set, Rotronix Instrument (UK) Ltd., West Sussex and UK). All the tests were performed in duplicate.

\section{Proximate analysis}

Proximate parameters viz., moisture, protein, fat and ash measurement were done according to the methods described by AOAC (1995). To determine the moisture percent, 10-g sample was dried at $100 \pm 5^{0} \mathrm{C}$ to constant weight. After analysis of total nitrogen using Kjeldahl method, a factor of 6.25 was used to derive total protein (\%). Fat percent was estimated using Soxhlet apparatus. Total ash was determined by using muffle furnace ( 550 $\pm 5^{0} \mathrm{C}$ for $6 \mathrm{~h}$ ). The crucible with residue was oven dried $\left(105 \pm 5^{0} \mathrm{C}\right)$ overnight and weighed. The crucible and its content were then transferred into a muffle furnace and ashing was done at $550 \pm 5^{0} \mathrm{C}$ for $4 \mathrm{~h}$, cooled and reweighed. The weight of ash was then calculated as $\mathrm{g} / 100 \mathrm{~g}$ of original sample.

\section{Fiber}

Crude fiber was estimated as per AOAC (1995) method using Fibra Plus Automatic Fibre Estimation System (Model no FES 6, Pelican equipment manufactured by Chennai, India) by alternate acid (1.25\% H2SO4) and alkali $(1.25 \% \mathrm{NaOH})$ digestion followed by washing with deionized water.

\section{Carbohydrate}

Carbohydrate percentage in product was determined by numerical formula as follows Carbohydrate $\%=100-($ Moisture $\%+$ Protein $\%+$ Fat $\%+$ Ash $\%+$ Fiber $\%)$.

\section{Energy}

Total calories content of cooked products were calculated as per the methods used by Verma et al., (2016). For 100-g portion using at water values for fat $(9 \mathrm{kcal} / \mathrm{g})$, protein $(4.02 \mathrm{kcal} / \mathrm{g})$ and carbohydrate $(4 \mathrm{kcal} / \mathrm{g})$.

\section{Shear force values}

Shear press of nuggets were conducted by Texture Analyzer (TMS-PRO, FTC, Maries Road, Sterling, VA, USA). The nuggets cube of uniform size $(1.0 \times 1.0 \times 1.0 \mathrm{~cm})$ was subjected to double compression cycle to $50 \%$ of their original height. The protocol described by the manufacturer was followed.

\section{Emulsion stability}

Emulsion stability was determined as per the method of Baliga and Madaiah (1970). $20 \mathrm{~g}$ of meat emulsion were packed in polyethylene bags, sealed and cooked at $80^{\circ} \mathrm{C}$ in a thermostatically controlled stirred water bath (Equitron, Model: 8414, Medica Instrument Mfg. Co., Mumbai, India) for $20 \mathrm{~min}$. Thereafter bags were removed from water bath, cooled to room temperature, cut open, 
cooked out fluid (fat, water and water soluble solids) was drained. The cooked emulsion mass weighed and expressed as percent emulsion stability.

\section{Cooking yield}

It is measured and expressed in percentage as the weight differ of cooked product and initial raw weight with the help of following formula

Weight of cooked nuggets

Cooking yield $(\%)=$---------- X 100

Weight of uncooked nuggets

\section{Moisture retention}

Values of moisture retention indicate the amount of moisture retained in the cooked product per $100 \mathrm{~g}$ and calculated as per the equation used by Kumar et al., (2007) as follows

(Percent cooking yield) $\mathrm{X}$ (Percent moisture in nuggets) Moisture retention $(\%)=$

100

\section{Fat retention}

Retention of fat was calculated as per the equation used by Kumar and Sharma (2003) as follows.

(Cooked weight X \% Fat in cooked nuggets) Fat retention $(\%)=$

(Uncooked weight $\mathrm{X}$ $\%$ Fat in uncooked nuggets)

\section{Water holding capacity}

Water holding capacity (WHC) was calculated per the method prescribed by Wardlaw et al., (1973). In a $100 \mathrm{~mL}$ polycarbonate centrifuge bottle, finely minced sample $(20 \mathrm{~g})$ was taken and then $30 \mathrm{~mL}$ of $0.6 \mathrm{M} \mathrm{NaCl}$ solution was added to it, mixed with glass rod and stirred for $2 \mathrm{~min}$ on a mechanical shaker. After holding for $15 \mathrm{~min}$ at $4^{\circ} \mathrm{C}$ in order to allow the effect of salt to reach equilibrium, the meat slurry was again stirred for $1 \mathrm{~min}$ on a shaker and immediately centrifuged at $5000 \mathrm{rpm}$ for 10 min at $-9^{\circ} \mathrm{C}$ in a centrifuge.

The supernatant volume was measured and difference between the added and decanted solution was expressed as percentage of the initial weight of sample.

\section{Instrumental color profile}

Color profile ( $\mathrm{L}^{*}, \mathrm{a}^{*}$ and $\mathrm{b}^{*}$ values) of cooked nuggets was measured using a Minolta Camera Co., Osaka, Japan. The colorimeter was calibrated with a white standard plate $(\bmod C R-A 43)$ and six measurements was taken on different surface of nuggets $(3 \times 3 \times 3$ $\mathrm{cm}$ size) at room temperature and. Color scores were expressed as $\mathrm{L}^{*}$ (lightness), $\mathrm{a}^{*}$ (redness) and $\mathrm{b}^{*}$ (yellowness).

\section{Texture Profile Analysis (TPA)}

Texture profile analysis (TPA) of spent hen meat nuggets were recorded using a texture analyzer (TMS-PRO, Food Technology Corporation, Maries Road, Suite 120 Sterling, VA, USA) following the procedures of Bourne (1978).

Nuggets were cut uniformly $(1.0 \times 1.0 \times 1.0$ $\mathrm{cm}$ ) were subjected to double-compression cycle reducing their size to half the original height using pretest speed of $5 \mathrm{~mm} / \mathrm{s}$, test speed of $1 \mathrm{~mm} / \mathrm{s}$, posttest speed of $1 \mathrm{~mm} / \mathrm{s}$, distance $10 \mathrm{~mm}$ and exposure time $3 \mathrm{~s}$. Texture profile parameters viz., hardness $(\mathrm{N})$, springiness $(\mathrm{mm}), \quad$ stringiness $(\mathrm{mm})$, cohesiveness, chewiness $(\mathrm{J})$, gumminess $(\mathrm{N})$ and resilience were estimated using in-built software (TMS-Pro) in the equipment from the force time plot. 


\section{Sensory evaluation}

Sensory evaluation for all the batches was carried out as per the international standards (ASTM, 1986). The sensory panelists were selected from the pool of Post-Graduate students and faculty of the department. All the panelists have very good knowledge about different meat quality attributes. Two session were conducted to detail about all the product characteristics and evaluation proforma of scale. A 8-point descriptive scale (where $1=$ extremely undesirable and $8=$ extremely desirable) was used to evaluate sensory attributes of spent hen meat chicken nuggets. The coded sample were served to each panelist at room temperature for evaluation. Drinking water was provided to cleanse the palate between successive evaluations.

\section{Statistical analysis}

Each experiment was conducted thrice to assure consistency of the results. The parameters for each sample were carried out in duplicate $(n=6)$. In case of color profile and instrumental texture analysis, triplicate $(n=9)$ observations were drawn for analysis whereas for sensory parameter seven panelists analyzed sample $(\mathrm{n}=21)$. The data obtained were subjected to statistical analysis for oneway analysis of variance (ANOVA). Duncan's multiple range test at 5\% significance level was applied to find out significant difference in mean (Snedecor and Cochran, 1989) and results were expressed as mean \pm standard error using SPSS-20 (SPSS Inc., Chicago, IL, USA).

\section{Results and Discussion}

Physico-chemical and proximate quality of spent hen meat (SHM) emulsion

Table 2 revealed that the $\mathrm{pH}$, moisture, protein, fat, ash, WHC and emulsion stability of SHM emulsion differ significantly ( $\mathrm{P}<$ $0.05)$ with incorporation of hydrated wheat bran.

The $\mathrm{pH}$ of all SHME added with hydrated wheat bran was significantly $(p<0.05)$ higher than control. The $\mathrm{pH}$ value of emulsion ranged from 5.64 to 6.18 . The highest $\mathrm{pH}$ values (6.18) were obtained from the SHME-12 indicating that the $\mathrm{pH}$ of emulsion increased with the increase in level of hydrated wheat bran in the formulation. Similar variations in $\mathrm{pH}$ was also observed by Yilmaz (2005) for meat ball as well as Talukder and Sharma (2010) for chicken meat patties. The moisture contents of emulsion decreased significantly $(\mathrm{P}<0.05)$ with the addition of wheat bran. The emulsion incorporated with highest level of hydrated wheat bran (12\%) recorded lowest moisture content. It might be due to replacement of high moisture lean meat (70-75 $\%)$ with low moisture wheat bran (12-15\%). Declining trend in moisture content of low fat meat balls with the addition of cereal bran was reported by Yasarlar et al., (2007) and Haung et al., (2011) for Turkish meat balls and Chinese-style sausages, respectively.

The protein and fat content were observed to be significantly $(\mathrm{P}<0.05)$ lower in wheat bran added chicken meat emulsion as compared to control. Addition of $12 \%$ hydrated wheat bran resulted in to lowest protein $(15.20 \%)$ and fat $(8.04 \%)$ as compared to other treatment. The lowering of moisture, fat and protein content with relative percentage in wheat bran incorporated SHM emulsion is attributed to the fact that it was added as a replacement of lean meat in the formulation and composition of wheat bran (protein 11-13\%, fat 2-3\% and moisture 12-15\%). Ash content of emulsion increased significantly $(\mathrm{P}<0.05)$ with addition of wheat bran. Emulsion with $12 \%$ hydrated wheat bran showed highest $(2.98 \%)$ ash content and lowest $(1.94 \%)$ for control meat emulsion. Our observations are in 
consonance with the findings of Talukder and Sharma (2010). Water holding capacity (WHC) followed an increasing trend with the increase in level of incorporation of wheat bran. WHC was significantly $(\mathrm{P}<0.05)$ higher in all treated emulsion than control. Increase in WHC with the incorporation of hydrated wheat bran might be due to ability of wheat bran to hold the moisture in the gel matrix (Tekin et al., 2010) and presence of soluble dietary fiber (Dawkins et al., 1999).

The emulsion stability was significantly $(\mathrm{P}<$ 0.05 ) increased in treated SHM emulsion than control. Among the treatments, SHME-12 exhibited highest emulsion stability and lowest in SHME-4. The increase in emulsion stability with the increase in levels of wheat bran might be due to entrapping and holding of moisture during application of heat $\left(80^{\circ} \mathrm{C}\right)$. Similar increase in emulsion stability with addition of fiber was observed by Huffman (1992) for lean pork sausage and Hughes et al., (1997) for frankfurters.

\section{Proximate composition of spent hen meat nuggets}

Results of proximate composition (moisture, protein, fat ash carbohydrate fiber, energy and moisture to protein ratio) of SHM nuggets influenced by hydrated wheat bran are presented in Table 3.

Decreasing trend was recorded for moisture content due to addition of hydrated wheat bran. The control had highest moisture content (63.32 \%) whereas FEN-12 HWB had lowest $(60.20 \%)$ moisture content. Decrease in moisture content might be due to the addition of dietary fiber; wheat bran with the replacement of lean meat. The average moisture content of lean meat is significantly $(\mathrm{P}<0.05)$ higher $(70-75 \%)$ than wheat bran (12-15 \%). Yasarlar et al., (2007) and Saricoban et al., (2009) also documented similar observation in Turkish meat balls and beef patties, respectively. The protein and fat contents of treated SHM followed a decreasing trend with the increase in additive amount of wheat bran. It is attributed to variation in formulation and composition of added wheat bran.

Further, the carbohydrate content increased significantly $(\mathrm{P}<0.05)$ in all the treated nuggets than control and it also followed an increasing trend with the additive level of wheat bran. Yilmaz (2005) also found decrease in protein and fat contents of low fat meat balls added with wheat bran.

The moisture-protein ratio was recorded significantly $(\mathrm{P}<0.05)$ higher in nuggets incorporated with $12 \%$ hydrated wheat bran (3.88) as compare to control and increased gradually with increase fiber content of products. Similar increased in MPR was observed by Verma et al., (2016) for low fat pork loaves added with inulin powder.

Results of statistical analyses indicated that ash, carbohydrate and fiber contents of SHM nuggets incorporated with hydrated wheat bran was significantly $(\mathrm{P}<0.05)$ higher than control. Among the treatments, highest content of ash (3.63\%), carbohydrate (5.16 $\%)$ and fiber $(6.98 \%)$ were recorded for FEN12. It might be due to more ash, carbohydrate and fiber content of wheat bran as compared to meat. Present findings are in agreement with that of Verma et al., (2016) who observed increase in ash, carbohydrate and fiber contents of functional pork loaves incorporated with fiber. The critical evaluation of Table 3 revealed that the total fat percentage in all the fiber enriched SHM nuggets is lower than $10 \%$, threshold limit for low-fat meat products (Keeton, 1994). Therefore, the developed products can be categorized under low-fat and high-fiber meat products. 
The energy (Kcal) content was significantly $(\mathrm{P}<0.05)$ higher in control as compare to all treatments. It might be due to high protein and fat content of control as compared to treated products.

Among the treatments, FEN-12 showed lower energy value which might be due to lower protein and fat content. The energy content in developed products was lower by 11.33 $14.80 \%$. Similar findings were observed by Verma et al., (2016) for low fat pork loaves.

\section{Physico-chemical quality of fiber enriched spent hen meat nuggets}

The results on physico-chemical properties of spent hen meat nuggets incorporated with different levels of hydrated wheat bran are presented in Table 4.

The $\mathrm{pH}$ of SHM nuggets increased with the addition of wheat bran and it followed an increasing trend with the level of incorporation of wheat bran.

It is attributable to higher innate $\mathrm{pH}(8.5)$ of wheat bran than lean meat $(5.86 \pm 0.13)$.

Further on close perusal of Table 2 and 4, it was revealed that $\mathrm{pH}$ of SHM nuggets was higher than their respective SHM emulsion.

It might be due to concentration of components with the moisture loss during cooking and deamination of proteins due to heating. Babu et al., (1994) also reported increase in $\mathrm{pH}$ on cooking due to increased salt concentration, loss of moisture and change in the net charge of proteins results from denaturation.

Lowest (0.878) water activity was recorded for FEN-12 HW and highest (0.901) in FEN-4 $\mathrm{HW}$, however water activity was significantly $(\mathrm{P}<0.05)$ higher in control than all treatments. This might be due to firm binding of water with wheat bran. Decrease in moisture content with the incorporation of wheat bran correlate with decrease in water activity $\left(\mathrm{a}_{\mathrm{w}}\right)$.

Incorporation of hydrated wheat bran significantly $(\mathrm{P}<0.05)$ increased the cooking yield, which might be due to ability of wheat bran to hold the moisture and fat in the matrix. Cofrades et al., (2000) also stated that increase in cooking yield with the incorporation of dietary fibers might be due to their water and fat binding properties.

It could be hypothesized that the mechanism responsible for moisture and fat retention might be related with the swelling of fibre in the wheat bran. Due to absorption of fat and interaction with the meat protein to form a matrix, which prevents the coalescence and migration of fat out of the product (Anderson and Berry, 2001).

The moisture retention percentage of wheat bran added nuggets increased significantly $(\mathrm{P}<0.05)$ with the increase in level of hydrated wheat bran. The higher percentage of moisture retention might be due to effective moisture binding properties of wheat bran which, prevented oozing out of moisture during cooking.

Increase in WHC with the addition of wheat bran in nuggets also responsible for increased moisture retention, which might be due to the ability of wheat bran to hold the moisture in the matrix (Tekin et al., 2010).

Similar increasing trend in fat retention percentage was observed in FEN-HWB. Dietary fiber present in wheat bran rich in hemicellulose and lignin, which helps to hold the fat due to longer length cellulose fiber that could retain more oil resulting in more fat retention after cooking (Ang, 1991). 
Table.1 Formulation of fiber enriched spent hen meat nuggets using hydrated wheat bran

\begin{tabular}{|l|c|c|c|c|}
\hline \multirow{2}{*}{ Ingredients $(\% \mathrm{w} / \mathrm{w})$} & \multirow{2}{*}{ CON } & \multicolumn{3}{|c|}{ Treatments } \\
\cline { 2 - 5 } & & FEN-4 & FEN-8 & FEN-12 \\
\hline Deboned meat & 70.00 & 66.00 & 62.00 & 58.00 \\
\hline Hydrated Wheat Bran (1:1) & 0.00 & 4.00 & 8.00 & 12.00 \\
\hline Refined oil & 7.50 & 7.50 & 7.50 & 7.50 \\
\hline Salt & 1.50 & 1.50 & 1.50 & 1.50 \\
\hline Sodium tetra \\
pyrophosphate & 0.20 & 0.20 & 0.20 & 0.20 \\
\hline Chilled water & 7.50 & 7.50 & 7.50 & 7.50 \\
\hline Refined wheat flour & 3.00 & 3.00 & 3.00 & 3.00 \\
\hline (Maida) & 2.50 & 2.50 & 2.50 & 2.50 \\
\hline Spice mix & 3.00 & 3.00 & 3.00 & 3.00 \\
\hline Condiments & 0.30 & 0.30 & 0.30 & 0.30 \\
\hline Sugar & 4.50 & 4.50 & 4.50 & 4.50 \\
\hline Egg allbumen & $120 \mathrm{ppm}$ & $120 \mathrm{ppm}$ & $120 \mathrm{ppm}$ & $120 \mathrm{ppm}$ \\
\hline Sodium nitrite
\end{tabular}

$\mathrm{CON}=$ Spent hen meat nuggets without hydrated wheat bran (HWB)

FEN-4 = Spent hen meat nuggets with $4.0 \%$ HWB, FEN- $8=$ Spent hen meat nuggets with $8.0 \%$ HWB FEN-12 $=$ Spent hen meat nuggets with $12.0 \%$ HWB

Table.2 Physico-chemical and proximate qualities of SHM emulsion incorporated with various levels of hydrated wheat Bran (HWB)

\begin{tabular}{|l|c|c|c|c|}
\hline \multicolumn{1}{|c|}{ Parameter } & CON & SHMIE-4 & SHMIE-8 & SHIMI-12 \\
\hline pH & $5.64 \pm 0.01^{\mathrm{a}}$ & $5.95 \pm 0.01^{\mathrm{b}}$ & $6.03 \pm 0.02^{\mathrm{c}}$ & $6.18 \pm 0.01^{\mathrm{d}}$ \\
\hline $\begin{array}{l}\text { Moisture } \\
(\%)\end{array}$ & $67.15 \pm 0.02^{\mathrm{d}}$ & $64.28 \pm 0.02^{\mathrm{c}}$ & $62.82 \pm 0.02^{\mathrm{b}}$ & $61.01 \pm 0.03^{\mathrm{a}}$ \\
\hline Protein (\%) & $16.50 \pm 0.03^{\mathrm{d}}$ & $16.10 \pm 0.01^{\mathrm{c}}$ & $15.60 \pm 0.03^{\mathrm{b}}$ & $15.20 \pm 0.02^{\mathrm{a}}$ \\
\hline Fat (\%) & $9.21 \pm 0.03^{\mathrm{d}}$ & $8.92 \pm 0.01^{\mathrm{c}}$ & $8.61 \pm 0.02^{\mathrm{b}}$ & $8.04 \pm 0.02^{\mathrm{a}}$ \\
\hline Ash (\%) & $1.94 \pm 0.01^{\mathrm{a}}$ & $2.54 \pm 0.01^{\mathrm{b}}$ & $2.77 \pm 0.02^{\mathrm{c}}$ & $2.98 \pm 0.01^{\mathrm{d}}$ \\
\hline WHC (\%) & $41.20 \pm 0.03^{\mathrm{a}}$ & $49.40 \pm 0.01^{\mathrm{b}}$ & $50.80 \pm 0.02^{\mathrm{c}}$ & $51.70 \pm 0.01^{\mathrm{d}}$ \\
\hline ES (\%) & $87.50 \pm 0.29^{\mathrm{a}}$ & $92.50 \pm 0.29^{\mathrm{b}}$ & $94.50 \pm 0.29^{\mathrm{c}}$ & $95.50 \pm 0.29^{\mathrm{d}}$ \\
\hline
\end{tabular}

Means with different superscripts in row differ significantly $(\mathrm{P}<0.05)(\mathrm{n}=6)$

$\mathrm{CON}=$ Spent hen meat emulsion without hydrated wheat bran (HWB),

SHME-4 = Spent hen meat emulsion with $4.0 \%$ HWB,

SHME-8 $=$ Spent hen meat emulsion with $8.0 \%$ HWB

SHME-12 = Spent hen meat emulsion with $12.0 \%$ HWB 
Table.3 Proximate composition of spent hen meat nuggets incorporated with various levels of hydrated wheat bran (HWB)

\begin{tabular}{|l|c|c|c|c|}
\multicolumn{1}{|c|}{ Parameter } & CON & FEN-4 & FEN-8 & FEN-12 \\
\hline Moisture & $63.32 \pm 0.06^{\mathrm{d}}$ & $62.82 \pm 0.05^{\mathrm{c}}$ & $61.50 \pm 0.06^{\mathrm{b}}$ & $60.20 \pm 0.03^{\mathrm{a}}$ \\
\hline Protein (\%) & $18.31 \pm 0.05^{\mathrm{d}}$ & $17.90 \pm 0.03^{\mathrm{c}}$ & $16.20 \pm 0.07^{\mathrm{b}}$ & $15.50 \pm 0.03^{\mathrm{a}}$ \\
\hline Fat (\%) & $11.44 \pm 0.06^{\mathrm{d}}$ & $9.40 \pm 0.02^{\mathrm{c}}$ & $8.99 \pm 0.01^{\mathrm{b}}$ & $8.53 \pm 0.02^{\mathrm{a}}$ \\
\hline Ash (\%) & $2.33 \pm 0.01^{\mathrm{a}}$ & $3.45 \pm 0.01^{\mathrm{b}}$ & $3.49 \pm 0.01^{\mathrm{c}}$ & $3.63 \pm 0.01^{\mathrm{d}}$ \\
\hline $\begin{array}{l}\text { Carbohydrate } \\
(\%)\end{array}$ & $1.54 \pm 0.01^{\mathrm{a}}$ & $1.88 \pm 0.01^{\mathrm{b}}$ & $4.07 \pm 0.01^{\mathrm{c}}$ & $5.16 \pm 0.01^{\mathrm{d}}$ \\
\hline Fiber (\%) & $3.06 \pm 0.01^{\mathrm{a}}$ & $4.55 \pm 0.02^{\mathrm{b}}$ & $5.75 \pm 0.03^{\mathrm{c}}$ & $6.98 \pm 0.03^{\mathrm{d}}$ \\
\hline Energy (Kcal) & $182.73 \pm 0.02^{\mathrm{c}}$ & $164.08 \pm 0.02^{\mathrm{a}}$ & $162.31 \pm 0.01^{\mathrm{ab}}$ & $159.72 \pm 0.02^{\mathrm{b}}$ \\
\hline $\begin{array}{l}\text { Moisture/Protein } \\
\text { Ratio }\end{array}$ & $3.46 \pm 0.01^{\mathrm{a}}$ & $3.50 \pm 0.01^{\mathrm{b}}$ & $3.80 \pm 0.02^{\mathrm{c}}$ & $3.88 \pm 0.01^{\mathrm{d}}$ \\
\hline
\end{tabular}

Means with different superscripts in row differ significantly $(\mathrm{P}<0.05)(\mathrm{n}=6)$

$\mathrm{CON}=$ Spent hen meat nuggets without hydrated wheat bran (HWB),

FEN-4 = nuggets with $4.0 \%$ HWB, FEN-8 = nuggets with $8.0 \%$ HWB, FEN-12 = nuggets with $12.0 \%$ HWB

Table.4 Physico-chemical parameters of spent hen meat nuggets incorporated with various levels of hydrated wheat bran (HWB)

\begin{tabular}{|l|c|c|c|c|}
\hline \multicolumn{1}{|c|}{ Parameter } & CON & FEN-4 & FEN-8 & FEN-12 \\
\hline pH & $6.30 \pm 0.01^{\mathrm{a}}$ & $6.38 \pm 0.01^{\mathrm{b}}$ & $6.43 \pm 0.01^{\mathrm{c}}$ & $6.45 \pm 0.01^{\mathrm{d}}$ \\
\hline Water activity $\left(\mathrm{a}_{\mathrm{w}}\right)$ & $0.921 \pm 0.003^{\mathrm{d}}$ & $0.901 \pm 0.002^{\mathrm{c}}$ & $0.889 \pm 0.001^{\mathrm{b}}$ & $0.878 \pm 0.001^{\mathrm{a}}$ \\
\hline Cooking Yield $(\%)$ & $88.54 \pm 0.02^{\mathrm{a}}$ & $92.13 \pm 0.04^{\mathrm{b}}$ & $93.88 \pm 0.06^{\mathrm{c}}$ & $94.34 \pm 0.03^{\mathrm{d}}$ \\
\hline $\begin{array}{l}\text { Moisture Retention } \\
(\%)\end{array}$ & $35.25 \pm 0.01^{\mathrm{a}}$ & $39.56 \pm 0.03^{\mathrm{b}}$ & $45.52 \pm 0.02^{\mathrm{c}}$ & $50.40 \pm 0.01^{\mathrm{d}}$ \\
\hline Fat Retention $(\%)$ & $90.23 \pm 0.07^{\mathrm{a}}$ & $93.35 \pm 0.02^{\mathrm{b}}$ & $95.95 \pm 0.01^{\mathrm{c}}$ & $98.65 \pm 0.05^{\mathrm{d}}$ \\
\hline Shear $(\mathbf{N})$ & $0.98 \pm 0.01^{\mathrm{a}}$ & $1.12 \pm 0.01^{\mathrm{b}}$ & $1.19 \pm 0.01^{\mathrm{c}}$ & $1.28 \pm 0.01^{\mathrm{d}}$ \\
\hline
\end{tabular}

Means with different superscripts in row differ significantly $(\mathrm{P}<0.05)(\mathrm{n}=6)$

$\mathrm{CON}=$ Spent hen meat nuggets without hydrated wheat bran $(\mathrm{HWB})$,

FEN-4 = nuggets with $4.0 \% \mathrm{HWB}, \mathrm{FEN}-8=$ nuggets with $8.0 \% \mathrm{HWB}, \mathrm{FEN}-12=$ nuggets with $12.0 \% \mathrm{HWB}$

Table.5 Instrumental color analysis of spent hen meat nuggets incorporated with various levels of hydrated wheat bran (HWB)

\begin{tabular}{|l|c|c|c|c|}
\hline \multicolumn{1}{|c|}{ Parameter } & CON & FEN-4 & FEN-8 & FEN-12 \\
\hline Lightness $\left(L^{*}\right)$ & $47.87 \pm 0.01^{\mathrm{a}}$ & $48.81 \pm 0.02^{\mathrm{b}}$ & $52.59 \pm 0.02^{\mathrm{c}}$ & $54.01 \pm 0.03^{\mathrm{d}}$ \\
\hline Redness $\left(a^{*}\right)$ & $9.89 \pm 0.02^{\mathrm{d}}$ & $8.22 \pm 0.02^{\mathrm{c}}$ & $7.72 \pm 0.03^{\mathrm{b}}$ & $7.24 \pm 0.02^{\mathrm{a}}$ \\
\hline Yellowness $\left(\boldsymbol{b}^{\mathrm{k}}\right)$ & $19.28 \pm 0.01^{\mathrm{a}}$ & $20.46 \pm 0.03^{\mathrm{b}}$ & $21.31 \pm 0.01^{\mathrm{c}}$ & $23.38 \pm 0.01^{\mathrm{d}}$ \\
\hline
\end{tabular}

Means with different superscripts in row differ significantly $(\mathrm{P}<0.05)(\mathrm{n}=9)$

$\mathrm{CON}=$ Spent hen meat nuggets without hydrated wheat bran $(\mathrm{HWB})$,

FEN-4 = nuggets with $4.0 \%$ HWB, FEN-8 = nuggets with $8.0 \%$ HWB, FEN-12 = nuggets with $12.0 \%$ HWB 
Table.6 Instrumental Texture profile of spent hen meat nuggets incorporated with various levels of hydrated wheat bran (HWB)

\begin{tabular}{|l|c|c|c|c|}
\hline \multicolumn{1}{|c|}{ Parameter } & CON & FEN-4 & FEN-8 & FEN-12 \\
\hline Hardness (N) & $13.64 \pm 0.03^{\mathrm{a}}$ & $14.10 \pm 0.03^{\mathrm{b}}$ & $14.75 \pm 0.03^{\mathrm{c}}$ & $16.01 \pm 0.02^{\mathrm{d}}$ \\
\hline $\begin{array}{l}\text { Springiness } \\
(\mathbf{m m})\end{array}$ & $11.94 \pm 0.06^{\mathrm{d}}$ & $10.57 \pm 0.03^{\mathrm{c}}$ & $10.24 \pm 0.01^{\mathrm{b}}$ & $9.52 \pm 0.02^{\mathrm{a}}$ \\
\hline \begin{tabular}{l} 
Stringiness $(\mathbf{m m})$ \\
\hline Cohesiveness
\end{tabular} & $18.32 \pm 0.02^{\mathrm{d}}$ & $16.74 \pm 0.03^{\mathrm{c}}$ & $16.04 \pm 0.04^{\mathrm{b}}$ & $15.20 \pm 0.01^{\mathrm{a}}$ \\
\hline Chewiness $(J)$ & $58.20 \pm 0.01^{\mathrm{a}}$ & $61.30 \pm 0.01^{\mathrm{b}}$ & $63.01 \pm 0.02^{\mathrm{c}}$ & $65.97 \pm 0.02^{\mathrm{d}}$ \\
\hline Gumminess $(\mathbf{N})$ & $6.91 \pm 0.01^{\mathrm{a}}$ & $7.24 \pm 0.01^{\mathrm{b}}$ & $7.28 \pm 0.02^{\mathrm{b}}$ & $7.55 \pm 0.03^{\mathrm{c}}$ \\
\hline Resilience & $0.87 \pm 0.01^{\mathrm{c}}$ & $0.85 \pm 0.01^{\mathrm{bc}}$ & $0.84 \pm 0.01^{\mathrm{ab}}$ & $0.83 \pm 0.01^{\mathrm{a}}$ \\
\hline
\end{tabular}

Means with different superscripts in row differ significantly $(\mathrm{P}<0.05)(\mathrm{n}=9)$

$\mathrm{CON}=$ Spent hen meat nuggets without hydrated wheat bran (HWB),

FEN-4 = nuggets with $4.0 \%$ HWB, FEN-8 = nuggets with $8.0 \%$ HWB, FEN-12 = nuggets with $12.0 \%$ HWB

Fig.1 Sensory properties of spent hen meat nuggets incorporated with various levels of hydrated wheat bran (HWB)

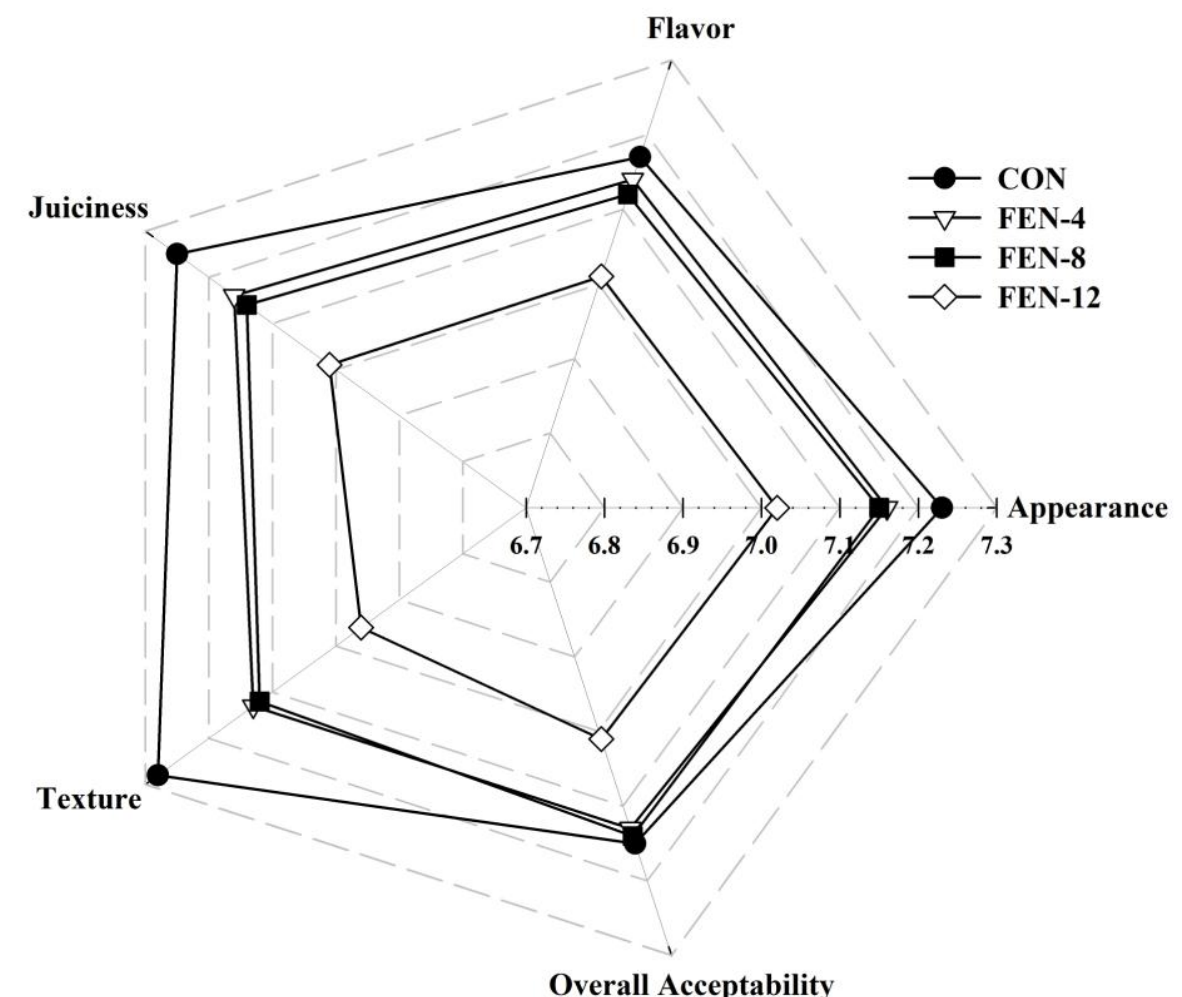

$\mathrm{CON}=$ Spent hen meat nuggets without hydrated wheat bran $(\mathrm{HWB})$,

FEN-4 = nuggets with $4.0 \%$ HWB, FEN-8 = nuggets with $8.0 \%$ HWB, FEN-12 = nuggets with $12.0 \%$ HWB 
It is observed that the shear press value increased significantly $(\mathrm{P}<0.05)$ with incorporation of wheat bran. Lowest $(0.98 \mathrm{~N})$ shear press value has been reported for control while highest for FEN-12 (1.28 N). It might be due to increase in firmness of texture, swelling of fibers with moisture and higher interaction of protein-fiber in the meat matrix. Chang and Carpenter (1997) also reported higher shear press value for frankfurters added with oat bran.

\section{Instrumental color analysis}

The first stimulus for the consumer acceptability of meat and meat products is color. Therefore, it is important to assess color attributes at the time of incorporation of various non-meat ingredients in meat products. Hunter $L^{*}, a^{*}$ and $b^{*}$ values of the SHM incorporated with different levels of hydrated wheat bran $(0,4,8$ and $12 \%)$ are presented in Table 5.

Hunter $L^{*}, a^{*}$ and $b^{*}$ values (Table 5) differed significantly $(\mathrm{P}<0.05)$ due to incorporation of different levels of hydrated wheat bran. Lightness values of spent hen meat nuggets increased significantly $(\mathrm{P}<0.05)$ with increase in level of hydrated wheat bran. Lowest $L^{*}$ values (lightness) were observed in control while highest values for FEN-12 HW which shows that incorporation of hydrated wheat bran resulted in lighter colored meat products. Decrease in color and appearance of hydrated wheat bran added nuggets were in consonance with increased in lightness $\left(L^{*}\right)$ Present findings are in agreement with Yilmaz (2005) for low fat meat balls and Yasarlar et al., (2007) for Turkish meat balls added with cereal bran.

Redness $\left(a^{*}\right)$ values were decreased significantly $(\mathrm{P}<0.05)$ with addition of hydrated wheat bran, higher the wheat bran lower the redness. It might be due to dilution of redness of lean meat with addition of white colored wheat bran. Similar declining trend was observed by Lin and Huang (2003) for low fat frankfurters incorporated with konjac/gellan gum mixed gels. The yellowness $\left(b^{*}\right)$ increased significantly $(\mathrm{P}<0.05)$ with the incorporation of hydrated wheat bran. It might be due to the presence of carotenoid pigments of wheat bran (Yilmaz, 2005). Hughes et al., (1997) also who reported increase in yellowness $\left(b^{*}\right)$ in frankfurters with the addition of oat bran.

\section{Texture profile analysis}

Comparative objective evaluation of different textural parameters in fiber enriched nuggets and control products (Table 6) clearly revealed that hardness of the product increased linearly with the increase in fiber content in the SHM nuggets. The hardness was measured highest in FEN-12 and lowest in control. Similar increase in hardness with addition of wheat bran was reported by Saricoban et al., (2009) in beef patties and Yilmaz (2005) in meat balls. The springiness and stringiness significantly $(\mathrm{P}<0.05)$ varied with the addition of hydrated wheat bran in SHM nuggets. The springiness and stringiness followed a decreasing trend with the increase in wheat bran content in the product. Springiness indicates the ability of the product regains its shape after deformation during the compression cycle (Texture Technologies, 2003). Springiness values were related to the elastic properties of nuggets, so decrease in the springiness indicated that the elasticity of nuggets is decreased with the increase in level of incorporation of hydrated wheat bran. It might be due to the formation of gel with the incorporation of hydrated wheat bran on cooking which lead to decrease in elasticity properties. Present findings are in agreement with the results reported by Sarıcoban et al., (2009) for beef patties incorporated with wheat bran. 
Cohesiveness is ability of food product to retain its structure after compression (Texture Technologies, 2003). Incorporation of hydrated wheat bran lead to decrease in cohesiveness significantly $(\mathrm{P}<0.05)$ and it followed a decreasing trend with the increase in the level of wheat bran in the formulation. Huang et al., (2005) has not observed any effect with addition of rice bran in pork meat balls. Increase in hardness and decrease in cohesiveness values with the incorporation of bran were observed by Yadav et al., (2016) for chicken sausage. Chewiness is resistance to compression. Chewiness and Gumminess values are directed by hardness, cohesiveness and springiness values of the product. Incorporation of hydrated wheat bran showed significant $(\mathrm{P}<0.05)$ increase in chewiness and gumminess values. Significantly $(\mathrm{P}<0.05)$ higher chewiness and gumminess values in FEN-12 HW might be due to their higher hardness values. Huang et al., (2005) reported increase in chewiness and gumminess values with the incorporation of rice bran on kungwan, a ground and emulsified pork meatballs.

Resilience is how well a product fights to regain its original position (Texture Technologies, 2003). It is observed that the resilience of SHM nuggets decreased significantly $(\mathrm{P}<0.05)$ due to incorporation of different levels of hydrated wheat bran. Decrease in resilience may be attributed to increase in hardness along with decrease in springiness and stringiness values with the incorporation of wheat bran. Saricoban et al., (2009) reported similar significant decrease in resilience with the addition of wheat bran in beef patties.

\section{Sensory quality}

Marketing of meat products at consumer level depends upon sensory quality. Sensory scores (Fig. 1) for all the quality attributes of SHM nuggets varied significantly $(\mathrm{P}<0.05)$ with the incorporation of different levels of hydrated wheat bran.

Appearance and color scores decreased with the increase in hydrated wheat bran content in the product. However, the sensory panelists rated FEN-4 and FEN-8 comparable. FEN-12 scored lowest and control scored highest appearance and color scores. These results are in conformity with our observations recorded by chromo color meter. However sensory panelists awarded significant $(\mathrm{P}<0.05)$ higher textual scores to control than all the treatments. These results can be correlated with the results of instrumental textural parameters

Flavour and juiciness scores varied in similar pattern, these were comparable for FEN-4 and FEN-8 and lowest for FEN-12 and highest for control amongst all the products. The diminution of meat flavor was noticed by the sensory panelist with the incorporation of higher amount of HWB on replacing the lean meat. The juiciness scores can be correlated with the decrease in moisture content in developed products.

The overall acceptability scores were highest for FEN-8 amongst treatments however it was statistically comparable with FEN-4 and control. The sensory panelists rated FEN-8 'Very Good to Excellent'. Similar significant $(\mathrm{P}<0.05)$ decrease in all the sensory attributes on addition of wheat and oat bran were observed by Talukder and Sharma (2010) for chicken meat patties and Yasarlar et al., (2007) for Turkish meat balls.

Results concluded that the fiber enriched spent hen meat nuggets can be successfully developed with the addition of pre-hydrated 8 $\%$ wheat bran in the formulation. The developed product has $200 \%$ higher fiber content, low-fat ( $<10 \%$ total fat), $15 \%$ lower calories and comparable sensory attributes to 
high fat (control) spent hen meat nuggets. Therefore, the authors recommend the results to meat industry for the commercial utilization of the developed technology.

\section{References}

Anderson, E. T., and Berry, B. W. (2001). Effects of inner pea fiber on fat retention and cooking yield in high fat ground beef. Food Research International, 34, 689-694.

Ang, J. F. (1991). Water retention capacity and viscosity effect of powdered cellulose. Journal of Food Science, 56, 1682-1684.

AOAC. (1995) Official Methods of Analysis, 16th edition, Association of Official Analytical Chemists, Washington, DC.

ASTM (1986) Physical requirements. Guidelines for sensory evaluation laboratories, STP 913. American Society for Testing and Materials, Pennsylvania.

Babu, N. P., Kowale, B. N., Rao, V.K., and Bisht, G. S. (1994) Effect of cooking and storage on lipid oxidation and development of cholesterol oxides in chicken meat. Indian Journal of Poultry Science, 29, 254-257.

Baliga, B. R., and Madaiah, N. (1970). Quality of sausage emulsion prepared from mutton. Journal of Food Science, 35, 383-385.

Barrosa, J. C., Munekata, P. E. S., Pires, M. A., Rodrigues, I., Andaloussi, O. S., Rodrigues, C., and Trindale, M. A. (2018). Omega-3- and fibre-enriched chicken nuggets by replacement of chicken skin with chia (Salvia hispanica L.) flour. LWT - Food Science and Technology 90, 283-289.

Bourne, M. C. (1978). Texture profile analysis. Food Technology, 33, 62-66.

Cappa, C., Laveli, V., and Mariotti, M. (2015). Fruit candies enriched with grape skin powders: physicochemical properties. LWT - Food Science and Technology, 62, 569-575.

Chang, H. C., and Carpenter, J. A. (1997). Optimizing quality of frankfurters containing oat bran and added water. Journal of Food Science, 62, 194-197.

Cofrades, S., Guerra, M. A., Carballo, J., Fernandez-Martin, F., and JimenezColmenero, F (2000). Plasma protein and soy fiber content effect on bologna sausage properties as influenced by fat level. Journal of Food Science, 65, 281-287.

Dawkins, N. L., Phelps, O., McMillin, K. W., and Forrester, I. T. (1999). Composition and physicochemical properties of chevon patties containing wheat bran. Journal of Food Science, 64, 597-600.

Dhingra, D., Michael, M., Rajput, H., and Patil, R. T. (2012). Dietary fibre in foods: A review. Journal of Food Science and Technology, 49, 255-266.

Haripriya, S., and Premakumari, S. (2010). Effect of wheat bran on diabetic subjects. Indian Journal of Science and Technology, 3 (3), 284-286.

Huang, S. C., Shiau, C. Y., Liu, T. E., Chu, C. L., and Hwang, D. F. (2005). Effects of rice bran on sensory and physicochemical properties of emulsified pork meatballs. Meat Science, 70, 613-619.

Huang, S. C., Tsai, Y. F., and Chen, C. M. (2011). Effects of wheat fiber, oat fiber and inulin on sensory and physicochemical properties of Chinese-style sausages. Asian-Australian Journal of Animal Science, 24, 875-880.

Huffman, D. L., Mikel, W. B., Egbert, W. R., Chen, C., and Smith, K. L. (1992). Development of lean pork sausage products. Cereal Food World, 37, 439442.

Hughes, E., Cofrades, S., and Troy, D. J. (1997). Effect of fat level, oat fiber and carrageenan on frankfurters formulated 
with 5, 12 and $30 \%$ fat. Meat Science, 453, 273-281.

Keeton, J. T. (1994). Low-fat meat productsTechnological problems with processing. Meat Science, 36, 261-276.

Khate, K. (2007). Development of designer pork sausages with low salt and fat. Ph.D. thesis. Deemed University; IVRI, Izatnagar, UP, India.

Kumar, M., and Sharma, B. D. (2003). Quality characteristics of low-fat ground pork patties containing milk coprecipitate. Asian-Australian Journal of Animal. Science, 16 (4), 588-595.

Kumar, M., Sharma, B. D, and Kumar R. R. (2007). Evaluation of sodium alginate as a fat replacer on processing and shelf-life of low-fat ground pork patties. Asian-Australian Journal of Animal. Science, 20 (4), 588-597.

Kumar, V., Biswas, A. K., Chatli, M. K., and Sahoo, J. (2011). Effect of banana and soybean hull flours on vacuumpackaged chicken nuggets during refrigeration storage. International Journal of Food Science and Technology, 46, 122-129.

Lin, K. W., and Huang, H. Y. (2003). Konjac/gellan gum mixed gels improve the quality of reduced fat frankfurters. Meat Science, 65, 749-755.

Sarıcoban, C., Yılmaz, M. T., and Karakaya, M. (2009). Response surface methodology study on the optimisation of effects of fat, wheat bran and salt on chemical, textural and sensory properties of patties. Meat Science, 83, 610-619.

Slavin, J. L. (2005). Dietary fiber and body weight. Nutrition, 21, 411-418.

Snedecor, G. W., and Cochran, W. G. (1989). Statistical methods, 8th edn. Iowa State University Press, Ames

Talukder, S., and Sharma, D. P. (2010). Development of dietary fiber rich chicken meat patties using wheat and oat bran. Journal of Food Science and Technology, 47, 224-229.

Tekin, H., Saricoban, C., and Yilmaz, M. T. (2010). Fat, wheat bran and salt effects on cooking properties of meat patties studied by response surface methodology. International Journal of Food Science and Technology, 45, 1980-1992.

Texture Technologies (2003). Textural profile analysis explained and annotated. $<$ www.texturetechnologies.com/texture _profile_analysis.html> (accessed 26.04.08).

Trout, E. S., Hunt, M. C., Johson, D. E. Clans, J. R., Castner, C. L., and Kroff, D. H. (1992) Characteristics of low fat ground beef containing texture modifying ingredients. Journal of Food Science, 57, 19-24.

Verma, A. K., Chatli, M. K., Mehta, N., Kumar, P., and Malav O. P. (2016) Quality attributes of functional, fiberenriched pork loaves. Agricultural Research, 5 (4), 398-406.

Wardlaw, F. R., McCaskill, L. H., and Acton, J. C. (1973) Effects of postmortem changes on poultry meat loaf properties. Journal Food Science, 38, 421-423.

WHO/FAO (2003). Diet, nutrition and prevention of chronic diseases. Geneva, Switzerland, WHO Technical report series, 916.

Yadav, S., and Malik, A. (2016). Study on development of dietary fiber enriched designer meat products. Ministry of Food Processing Industries, Govt. of India; New Delhi: 2016. F.No.56/MFPI/R\&D/2011.

Yadav, S., Malik, A., Pathera, A., Islam, R., and Sharma, D. (2016). Development of dietary fiber enriched chicken sausages by incorporating corn bran, dried apple pomace and dried tomato pomace. Nutrition and Food Science, 46, 16-29. 
Yasarlar, E. E., Daglioglu, O., and Yilmaz, I (2007). Effect of cereal bran addition on chemical composition, cooking characteristics and sensory properties of Turkish meat balls. Asian Journal of Chemistry, 19, 2353-2361.
Yilmaz, I. (2005). Physicochemical and sensory characteristics of low fat meat balls with added wheat bran. Journal of Food Engineering, 69: 369-373.

\section{How to cite this article:}

Sandeep Narayan Rindhe, Manish Kumar Chatli, Rajesh Vishwanath Wagh, Pavan Kumar, Om Prakash Malav and Nitin Mehta. 2018. Development and Quality of Fiber Enriched Functional Spent Hen Nuggets Incorporated with Hydrated Wheat Bran. Int.J.Curr.Microbiol.App.Sci. 7(12): 3331-3345. doi: https://doi.org/10.20546/ijcmas.2018.712.384 